Preliminary Communication

UDC 341.231.14:341:347.6

DOI: https://doi.org/10.22598/iele.2020.7.1.5

\title{
IS IT LEGITIMATE TO LIMIT THE PROCREATIVE RIGHT?
}

\section{Barbara Preložnjak*}

\begin{abstract}
International human rights law sets out the entitlements and freedoms of individuals to start a family which is considered to be a natural and fundamental group unit of society. Foundation of a family is usually related to the idea of creation and continuation of life that involves the procreative capacity of family members and is consolidated through the actual act of procreation. However, in the practice, it means that some individuals may face with procreation problems that are obstacles to the efficient realization of the procreative right. The law has a solution for overcoming the problem as it guarantees access to the assisted procreative facilities that have the aim to enable procreation. Thus, the procreation becomes possible with the involvement of the third party. It is especially noticeable in the case where the law allows the donation of the reproductive cells or childbearing for potential procreators (surrogacy). Those procreation novelties deprived the procreation of its private characteristics and made procreation public. The most importantly the law enabled that human body, with it related the act of childbearing and child itself become the subject of various agreements between adults. That leads to the question of whether the procreation right should be limited, as it makes possible that human being and parts of its body become the commodity. To answer that question it is needed to determine the scope of the procreation right itself, and view it in relation to the competing rights of all subjects in the procreation process. The analysis of the moral aspect of the procreative right is also important as its intrinsic value and its relation to other rights could offer an answer which right should prevail in the case when procreative right conflict with some other rights.
\end{abstract}

KEYWORDS: the freedom to procreate, limits of the right, intrinsic values, children right's

* Barbara Preložnjak, University of Zagreb Faculty of Law, Croatia; barbara.preloznjak@ pravo.hr. 


\section{INTRODUCTION}

The procreation is grounded in the strong interest of creating a child which can be motivated by many different reasons such as to give meaning or add value to life, to carry on the family name, to be like other friends, to give in to family pressure, to pass on genes to the next generation, and etc. ${ }^{1}$ The procreation is considered to be central to individual identity and there is a consensus that everyone can freely choose when, whether, and how many children to have. However, the procreative right is not explicitly guaranteed as a human right in the European Convention for the Protection of Human Rights and Fundamental Freedoms (ECHR). ${ }^{2}$ ECHR regulates the right to marry and to found a family and the right to private and family life. Thus, Article 8(1) of the ECHR prescribes that the private and family life, home and correspondence must be respected. Article 12 of the ECHR guarantees the rights to marry and to found a family to men and women of marriageable age, according to the national laws that are governing the exercise of this right.

The notion that the semantic content of the procreative right is absent from ECHR imposes the question whether the procreative right is the legal right that can be derived from the right to marry and to found a family or the right to private and family life. The answer to that question can be positive if we accept assumption that legal norms that regulate private and family life have certain value or they serve to some interest, purpose or enforce some principle that exists independently of the rule itself. However, the existent interpretation does not per se serve to the underlying interest, purpose or principle and thus may have to be interpreted differently. When that interpretative attitude is adopted towards a legal norm that regulates the right to private and family life, the legal norm of the ECHR is no longer applied automatically. Instead, the content of the legal norm that regulates the private and family life becomes more dependent on the values underlying it. That kind of interpretative attitude is recognized by the European Court of Human Rights (ECtHR) whose case law has been particularly relevant in determining whether procreative right could be derived as legal right from right marry and to found a family (Article 12 ECHR) or right to private and family life (Article 8(1) ECHR).

\footnotetext{
Boivin J, Pennings G. (2005). Parenthood should be regarded as a right. Archives of Disease in Childhood, 90(8), 784-785. doi:10.1136/adc.2004.064485.

2 Council of Europe, European Convention for the Protection of Human Rights and Fundamental Freedoms, as amended by Protocols Nos. 11 and 14, 4 November 1950, ETS 5, available at: https://www.refworld.org/docid/3ae6b3b04.html [accessed 20 January 2020].
} 
Although at first glance it seems that the appropriate basis for promoting and protecting interest to procreate can be found in the right to marry and to found a family (Article 12 ECHR), the ECtHR thinks that it is difficult to interpret it as procreative right. ${ }^{3}$ The reason for that standpoint lies in the notion that the right to marry and to found a family entails a narrow understanding of what constitutes a family, requires the existence of a couple and does not protect the right to procreate. ${ }^{4}$ However, the ECtHR analysis of Article 8(1) of the ECHR supported the putative right to procreate and recognized its applicability to access to the assisted procreative facilities.

As procreative right is not explicitly guaranteed by ECHR but interpreted from norms of Article 8(1), the author will first analyze the scope of the procreative right under the notion of the ECtHR case law. Then the procreative right defined by ECtHR will be further analyzed from standpoint of Hohfeld analysis of law to define its content and legal relations that procreative rights create among procreators, child and third persons involved in procreation process. Then the right to procreate will be confronted with the rights of other participants in the procreation process that is determined with the help of Hohfeld analysis. To see which right will prevail in the case of the conflict of rights, the Griffin theory of human rights will be used. In conclusion, the author will give a review of what happens when the procreative right conflicts with the rights of the child or the third party (e.g. surrogate mother). Also in the conclusion, the author will offer the answer to the question of how the conflict can be resolved and whether can it result with the limitation of the procreative right.

\section{INTERPRETATION OF THE PROCREATIVE RIGHT UNDER ARTICLE 8(1) OF ECHR IN THE LIGHT OF ECTHR CASE LAW}

In the case, Evans $\mathrm{v}$ the United Kingdom the applicant was a woman who wished to have implanted the embryos that are created through artificial insemination facility. ${ }^{5}$ The embryos were created by using woman's eggs and the sperm of her ex-partner. ${ }^{6}$ However, the woman's ex-partner withdrawal consents to embryo use by her. ${ }^{7}$ The interest of woman and her ex-partner to

\footnotetext{
Palomares, G. C. (2016).Right to Family Life and Access to Medically Assisted Procreation in the Case Law of the European Court of Human Rights, In M. G. Pascual and A. T. Pérez (Eds.),The Right to Family Life in the European Union (pp. 99-114). New York: Routledge.

4 Ibid.

5 Case of Evans v the United Kingdom, Application No. 6339/05, Judgement 10 April 2007.

6 Ibid.

7 Ibid.
} 
become genetic parents were irreconcilable, and the right to private life as a procreative right, according to the ECtHR interpretation, did not serve the interest of respect for human dignity and free will, nor to a desire to ensure a fair balance between them. ${ }^{8}$ To strike a fair balance between the competing interests of the woman and her ex-partner, the ECtHR concluded that right to respect the decision to become a genetically related mother carried no more weight than the right to respect for the decision not to have a genetically related child with the mother. ${ }^{9}$ In its judgment, the ECtHR for the first time interpreted the right to private life, guaranteed by Article 8(1) ECHR, as the procreative right that serves to protect the underlying interest of men and woman to make a decision to (not) become parents in the genetic sense. ${ }^{10}$

In the judgment Dickson $\mathrm{v}$ the United Kingdom, the ECtHR extended procreative right to right to family life by interpreting the right to family life as the right to access to artificial insemination facilities. ${ }^{11}$ The applicants were a couple whom both wanted to conceive a child through artificial insemination guaranteed by domestic law which was the only way they could become parents in the genetic sense as the man was a prisoner with a minimum 15-year sentence to serve for murder. ${ }^{12}$ Because of the age of the woman they had little chance of conceiving after men release. The ECtHR considered that in this case, the value of the right to family life is to protect the interest to access to the artificial insemination facilities to achieve genetic reproduction, which should not be restricted by the public interest to hold trust in the penal system or by the interests of the future child. ${ }^{13}$

In both previous judgments, the ECtHR has interpreted the right to private and family life as the right that protects interest to become the parent in the genetic sense and the interest to have access to artificial insemination facilities. Besides, the issue of applicability of Article 8 is not controversial since access to medically assisted procreation was in both cases guaranteed under the domestic law. By contrast, in the cases of S.H. and Others v Austria, and Costa and Pavan v Italy, domestic law prohibited in general terms the access to some artificial insemination facilities that the applicants wanted to use heterologous techniques in S.H., and pre-implantation genetic diagnosis in Costa and Pavan.

8 Case of Dickson v the United Kingdom, Application No. 44362/04, Judgement 4 December 2012.

9 Case of Evans v the United Kingdom, op. cit. (fn. 5).

10 Ibid.

11 Case of Dickson v the United Kingdom, op. cit. (fn. 8).

12 Ibid.

13 Ibid. 
In its judgment S.H. and Others v Austria, the ECtHR found that the right of two couples to conceive a child and to make use of medically assisted procreation for that purpose was protected by Article 8, as such a choice was an expression of private and family life. ${ }^{14}$ The ECtHR considered that concerns based on moral considerations or the social acceptability of medically assisted procreation must be taken seriously but they are not in themselves sufficient reasons for a complete ban on a specific artificial procreation technique such as ovum donation. ${ }^{15}$

In the judgement Costa and Pavan v Italy, the ECtHR decided that the procreative right should be interpreted in the terms of the right to family life (Article $8(1)$ of the ECHR) even in the situations when the use of medically assisted procreation and pre-implantation genetic diagnosis is reserved for couples that are neither sterile nor infertile. ${ }^{16}$ Thus, the ECtHR identified the breach of procreative right for the Italian couple that were not sterile or infertile but wanted to conceive the child with the help of the artificial insemination facilities to have pre-implantation genetic diagnosis for the genetic disease (cystic fibrosis) of which they were carriers and that could be passed to their potential future child. By this decision, the ECtHR not only interpreted procreative right from Article 8(1) of the ECHR but it created new "autonomous" right that did not exist before in the domestic legal system. ${ }^{17}$

\section{REDEFINING THE PROCREATIVE RIGHT}

The ECtHR by its interpretation gave to the private and family life, the meaning of the right to have genetic children without actions of the state that prohibit or restrict access to artificial insemination facilities as it undermines the individual autonomy to procreate which is the only concern of the individual.

Thus interpreted private and family right can be summed up to the notion of the procreative right which is a bundle of various Hohfeldian elements. ${ }^{18} \mathrm{In}$ Hohfeld's terms, procreation involves the liberty of the legal subject that is by the legal norm, that guarantees private and family life, entitled to have children by natural conception or with the help of the artificial insemination facil-

${ }_{14}$ Case of S. H. and Others v. Austria, Application No. 57813/00, Judgement 3 November 2011.

15 Ibid.

16 Costa and Pavan v Italy, Application No. 54270/10, Judgement 28 August 2012.

17 Ibid.

18 Hohfeld, W. N. (1917). Fundamental Legal Conceptions as Applied in Judicial Reasoning, The Yale Law Journal, 26(8), pp.710-770.DOI: 10.2307/786270. 
ities. The procreative liberty, as the norm of the ECtHR judicature identifies, is and should be protected from any physical interference in its implementation or omission of its performance. That means even the protection from the legislator who could prohibit procreation with legal norms. The procreative right also gives to the procreators the power to alter their legal relations or legal relations of as actors involved in procreation (e.g. donors of reproductive cells, medical intuitions and state) and as well of the prospective child or children. The norms that regulate the private and the family right also give to the legal subjects the claim-right to procreate without of interference by anyone else, including the state into his/her decision to have children (negative right to procreate). Depending on one's view of interference, the duty not to interfere might prohibit such things as restrictions regarding access to artificial insemination facilities that aim to help in bypassing the procreation obstacles (e.g. infertility). However, if we argue for a positive right to procreate, this includes a claim-right to assistance and duty on others through the state to provide it. That would mean, for example, that the medical institutions would have the duty to make available artificial insemination facilities to all without any restrictions. Finally, the procreative right involves immunities, in that others, including the state, cannot derogate (are disabled from derogating) the procreative claim rights, liberties, and powers of the prospective procreators.

On the other hand, the procreation creates the child, which is a new life that is the genesis of the state's interest. If the new life, and thus the state's interest, has its origin in the conduct of procreation, then procreation itself could be the subject to the state's control. Conceptually, then, there is no personal autonomy in the decision to create the child, which is essentially interpersonal. Not procreating is personal but procreating is interpersonal. This distinction takes procreation out of the rubric of private and personal acts, defining the first limitations on the procreative right. ${ }^{19}$ Thus, the procreative liberty is not absolute or unrestricted liberty, yet it may rightfully be curtailed when the procreation causes excessive harm to the community or to the child himself or herself. ${ }^{20}$ In that sense, the procreative right includes powers of the state over the procreator and the others who automatically enter into legal relations that aim to create the prospective child or children, and as well powers over the prospective child or children themselves. Hosts of liabilities are likewise created by the act of procreation, including those upon the state, with special liabilities for co-procreators and other persons associated with the prospective child or children.

19 Dillard, Carter J. (2007). Rethinking the Procreative Right, Yale Human Rights and Development Journal, 10(1), pp. 3-63.

20 Ibid. 


\section{THE RESTRICTION OF THE PROCREATIVE RIGHT}

The procreative right has intrinsic values such as immortality through descendants, living vicariously through one's children, getting a "second chance," intimate relations with one's offspring, the satisfaction of the longing for home or nest with close relations and belonging, and the interest of couples to found a family. ${ }^{21}$ Those intrinsic values of procreative right reflect in "the central importance to individual meaning, dignity, and identity" and as well are of a "great significance for personal identity and happiness". ${ }^{22}$ In order words, the procreation could be interpreted as the right that is intrinsically valuable for every human being as it serves for its self-fulfillment. However, the procreative right cannot be understood in isolation, as it represents the act of creating another person. Thus, the procreative right creates particular legal relations between several legal subjects that are involved in the process of childbearing and can easily come into the conflict with their right and values that are underlying them. If we accept the theory of John Griffin that the rights have differing weights relative to the values they protect, the value of self-fulfillment that is protected by procreative right can, for example, come into the conflict with values of different child rights. ${ }^{23}$

It especially comes into question in the example of the surrogacy when one of the commissioning parents does not have a genetic link with the child. If we interpret surrogacy as an artificial reproductive facility that may help individuals and couples to become genetic parents when other methods of reproduction are not successful or applicable to their life situation, then we can easily claim that surrogacy aims to achieve the fulfillment of the procreative right. However, surrogacy creates a legal relationship between commissioning parents, surrogacy mother and the child, which all have specific rights that arise from that particular legal relationship. If their rights and its underlying values come in conflict, according to J. Griffin, the right is weightier if it is more central to the personhood of its holder. ${ }^{24}$ Let us again assume that procreative

21 Shanner, L. (1995). The Right to Procreate: When Rights Claims Have Gone Wrong, McGill Law Journal, 40(4), pp. 823-874.; Statman, D. (2003). The Right to Parenthood: An Argument for a Narrow Interpretation, Ethical Perspect, 10(3-4), pp. 224-235.

22 Robertson, J. A. (1995). Liberalism and the Limits of Procreative Liberty: A Response to My Critics, Washington Lee Law Review, 52(1), pp. 233-267.; Priaulx, N. (2008). Rethinking Progenitive Conflict: Why Reproductive Autonomy Matters, Medical Law Review, 16(2), pp. 169-200. https://doi.org/10.1093/medlaw/fwn009.

23 Griffin, J. (2001). Rights in Conflict, In M. Friedman, L. May, K. Parson, J. Stiff (Eds.), Rights and Reason: Essays in Honor of Carl Wellman (pp. 105-120). Springer - Science \&Bussiness Media, B. V.

24 Ibid. 
right supposes the value of procreator's self-fulfillment which could be important in defining him as a person. On the other hand, in case of surrogacy, if at least one gamete is donated, the procreative right and its intrinsic value can, for example, conflict with the certain right of the child that does not carry the same intrinsic value as procreative right.

Thus, the procreative right can come into the conflict with the child's right to know the parents, guaranteed by Article 7(1) of the Convention on the Rights of the Child (CRC), and the values that this right protects. ${ }^{25}$ The right to know the parents is central to child's personhood as it defines child's identity that is interrelated with the notion of genetic origins that gives a true and genuine personal, legal and family identity. ${ }^{26}$ Therefore, besides the right to know the parents, the procreative right can come into the conflict with the right to an identity that is guaranteed by Article 8 of the CRC. ${ }^{27}$ The intrinsic value of those rights was confirmed by the ECtHR, which held that it is from vital interest for every human being to receive the information necessary to uncover the truth about an important aspect of their personal identity. ${ }^{28}$ Moreover, the empiric research confirmed that the genetic origins are essential for physical and psychosocial well-being and that consequently, lack of access to this information constitutes actual harm. ${ }^{29}$

On the other hand, the procreative right in the case of surrogacy arrangements can come into the conflict with the surrogate mother's right not to be subjected to inhuman or degrading treatment (Article 3 ECHR) or the right that her body and its parts shall not, as such, give rise to financial gain (Article 21 of the Convention for the Protection of Human Rights and Dignity of the Human Being with regard to the Application of Biology and Medicine: Convention on Human Rights and Biomedicine (ETS No 164) (CHRB)). In other words, the value of self-fulfillment can come into the conflict with the value of dignity, which outweighs, as the surrogate mother is often seen as a means to reach the intending procreation goal. As the role of the surrogate mother is to provide

\footnotetext{
25 Convention on the Rights of the Child, United Nations, Treaty Series, vol. 1577, p. 3.

26 Hodgson, D. (1993). The international legal protection of the child's rights to a legal identity and the problem of statelessness, International Journal of Law, Policy and the Family, 7(2), pp. 255-270. https://doi.org/10.1093/lawfam/7.2.255; Wade, K. (2017). The regulation of surrogacy: a children's rights perspective, Child and Family Law Quarterly, 29(2), pp. 113-131.; Ravitsky, V. (2017). The right to know one's genetic origins and cross-border medically assisted reproduction, IsraelJournal of Health Policy Research, 6(3), pp. 2-3. doi: 10.1186/s13584016-0125-0.

27 Convention on the Rights of the Child, op. cit. (fn. 25).

28 Hodgson, D., op. cit. (fn. 26), pp. 255-270.; Wade, K. op. cit. (fn. 26), pp. 113-131.; Ravitsky, V. op. cit. (fn. 26), pp. 2-3. doi: 10.1186/s13584-016-0125-0.

29 Ibid.
} 
a service to the intending parents, her body and, more precisely, her womb is used as a true object. Thus, the achievement of procreation through surrogacy arrangement means nothing more than the commodification of the surrogate mother that is used as a human incubator.

\section{CONCLUSION}

It is natural for human beings to have a desire to have genetic children as they can bring an increased sense of meaning into their lives. Thus, not having children imply not attaining plenitude, not being ontologically fulfilled. The procreative right is also recognized as an important right interpreted by ECtHR from right to private and family life (Article 8(1) ECHR). To achieve procreation goal, the individuals and the couples have the freedom to decide whether to have children without the interference of others, including the state and the power to alter their legal relations or legal relations of the actors involved in the procreation process. In addition, the procreative right gives the prospective procreators the claim right to the state and the others to sustain from interference into their decision to procreate or even the claim right to the state to enable them access to artificial insemination facilities if they need help to have a genetic child. However, we cannot say that the prospective procreators should be immune from derogation of their procreative claim rights, liberties, and powers. The reason for this standpoint is especially noticeable when the enjoyment of having a genetic child is fully dependent on artificial insemination facilities. In that case, exercising the procreative right could help potential procreators to achieve the intrinsic value of self-fulfillment; however, it may conflict with the rights of other actors of procreation process and with values that those rights protect or aim to achieve for their holders. If we take an example of surrogacy, which is among some considered as new artificial insemination facility, the procreative right conflicts with the child right to know his/her parents and right to identity and as well with surrogate mother's right to bodily integrity. When these rights conflict the question is which right should prevail? According to the J. Griffin theory of rights, priority needs to be given to the right with intrinsic value that is more important to the personhood. Thus, in the case of surrogacy, the value of procreator's self-fulfillment may confront with values of self-identity and dignity. That leads us to the conclusion that in procreation arrangements such as surrogacy, children are at the mercy of adult decision-making that only aims to pursue adult happiness and personal fulfillment by manufacturing a child into existence through procreation technologies. We should not forget that the children are not the commodity and they should not exist for the fulfillment of adults. Therefore, children's rights should not be abused in favor of adult desires, especially through the normalization and promotion of family structures and 
technological advancements that require a child to lose their identity by losing a mother or father. Also in surrogacy arrangements, the procreative right conflicts with surrogate mother's right to bodily integrity as she uses her body as an instrument for the financial gain which causes conflict between intrinsic values of the self-fulfillment of potential procreators (individuals or couple) and intrinsic value of surrogate mother dignity. The value of self-fulfillment should not prevail over the value of dignity, as, by their nature, humans are not entities that can be instrumentalized and used as mere means to an end. ${ }^{30} \mathrm{Al}-$ though it is not acceptable to interfere with one's procreative right, as it is an intimate and personal area of human life, the procreative right should not be unlimited. Intentionally depriving children of their right to know and to have contact with their biological parents and wider family, or their right to be born from natural biological origins, or depriving children and surrogate mothers from their right not to use body parts as commodity represent a severe breach of human rights and their intrinsic values. Therefore, we must not forget that all these rights are central to the personhood of the child and the surrogate mother and cannot be traded off with procreative right that rests on the value of the self-fulfillment and which strives to make children an object designed for adults' selfish desires.

\section{LITERATURE}

1. Boivin J, Pennings G. (2005). Parenthood should be regarded as a right. Archives of Disease in Childhood, 90(8), 784-785.

- DOI: https://doi.org/10.1136/adc.2004.064485

2. Dillard, Carter J. (2007). Rethinking the Procreative Right, Yale Human Rights and Development Journal, 10(1), pp. 3-63.

3. Griffin, J. (2001). Rights in Conflict, In M. Friedman, L. May, K. Parson, J. Stiff (Eds.), Rights and Reason: Essays in Honor of Carl Wellman (pp. 105-120). Springer - Science \&Bussiness Media, B. V.

4. Hodgson, D. (1993). The international legal protection of the child's rights to a legal identity and the problem of statelessness, International Journal of Law, Policy and the Family, 7(2), pp. 255-270.

- DOI: https://doi.org/10.1093/lawfam/7.2.255

5. Hohfeld, W. N. (1917). Fundamental Legal Conceptions as Applied in Judicial Reasoning, The Yale Law Journal, 26(8), pp.710-770.

- DOI: https://doi.org/10.2307/786270

6. Kant, I. (2012). Groundwork for the metaphysics of morals. New York: Cam-

30 Kant, I. (2012). Groundwork for the metaphysics of morals. New York: Cambridge University. 
bridge University.

- DOI: https://doi.org/10.4324/9780203981948

7. Palomares, G. C. (2016).Right to Family Life and Access to Medically Assisted Procreation in the Case Law of the European Court of Human Rights, In M. G. Pascual and A. T. Pérez (Eds.),The Right to Family Life in the European Union (pp. 99-114). New York: Routledge.

8. Priaulx, N. (2008). Rethinking Progenitive Conflict: Why Reproductive Autonomy Matters, Medical Law Review, 16(2), pp. 169-200.

- DOI: https://doi.org/10.1093/medlaw/fwn009

9. Ravitsky, V. (2017). The right to know one's genetic origins and cross-border medically assisted reproduction, IsraelJournal of Health Policy Research, 6(3), pp. 2-3.

- DOI: https://doi.org/10.1186/s13584-016-0125-0

10. Robertson, J. A. (1995). Liberalism and the Limits of Procreative Liberty: A Response to My Critics, Washington Lee Law Review, 52(1), pp. 233-267.

11. Shanner, L. (1995). The Right to Procreate: When Rights Claims Have Gone Wrong, McGill Law Journal, 40(4), pp. 823-874.

12. Statman, D. (2003). The Right to Parenthood: An Argument for a Narrow Interpretation, Ethical Perspect, 10(3-4), pp. 224-235.

- DOI: https://doi.org/10.2143/EP.10.3.503888

13. Wade, K. (2017). The regulation of surrogacy: a children's rights perspective, Child and Family Law Quarterly, 29(2), pp. 113-131.

\section{LEGISLATION}

1. Convention on the Rights of the Child, United Nations, Treaty Series, vol. 1577, p. 3.

2. Council of Europe, European Convention for the Protection of Human Rights and Fundamental Freedoms, as amended by Protocols Nos. 11 and 14, 4 November 1950, ETS 5, available at: https://www.refworld.org/docid/3ae6b3b04.html [accessed 20 January 2020].

\section{CASES}

1. Case of Evans v the United Kingdom, Application No. 6339/05, Judgement 10 April 2007.

2. Case of Dickson v the United Kingdom, Application No. 44362/04, Judgement 4 December 2012.

3. Case of S. H. and Others v. Austria, Application No. 57813/00, Judgement 3 November 2011.

4. Costa and Pavan v Italy, Application No. 54270/10, Judgement 28 August 2012. 
